\title{
Familial Correlations for Age at Onset and Age at Death in Huntington's Disease
}

\author{
C. J. BRACKENRIDGE \\ From the Department of Psychiatry, University of Melbourne, Victoria, Australia
}

An estimate of the heritability of the age at onset of Huntington's disease is useful for several purposes. It enables the role of allelic modifying genes to be assessed and in some circumstances carries implications for genetic counselling. Thus if the correlation between affected parent and offspring pairs with respect to age at onset or at death is indistinguishable from zero, allelic modifiers may operate (Penrose, 1948). At the other extreme a correlation close to unity, which could arise from the direct action of several different genes (Haldane, 1941), would greatly assist prediction since sibs at risk would succumb to the disease at comparable ages.

Previous investigations touching on interclass (parent-child) and intraclass (sib-sib) correlations in Huntington's disease have not examined the effects of sex, type of neurological sign at onset, or order of symptoms during the course of the disorder. These were some of the questions which prompted the work to be described. Bell (1934) and Reed and Chandler (1958) have noted the bias which is caused by the omission of potential cases in favour of those of relatively early onset. The present study also shows the powerful disturbing effect of differences in ages at onset and death between generations on both types of correlation. The ultimate aim was to determine the genetic mechanism involved in their inheritance.

\section{Material and Methods}

Details of subjects affected with Huntington's disease were taken from case reports and pedigree studies collected without known bias from the literature. Members of sibships were ascertained if they formed a pair with another sib or with a parent, the age at onset or age at death being known for both persons. The 167 literature references yielded 814 sibships containing 1671 affected sibs born to 653 parents (Appendix I, p. 28). The ages at onset and at death of sibs and parents, subdivided according to sex, are reported in Tables A to D of Appendix II (p. 29). The source

Received 16 August 1971. references for the series are given separately in Appendix III (p. 30).

Sib-sib correlation coefficients and estimates of their standard errors were calculated from analyses of variance (Fieller and Smith, 1951/1952; Smith, 1956/1957). Parent-child correlation coefficients were determined by the product-moment method and the approximation $\left(1-r^{2}\right) / \sqrt{ } n$, where $r$ is the coefficient of correlation and $n$ is the number of pairs, was used to derive their standard errors. Tests of homogeneity and the significance of differences of parent-child coefficients from 0 and 0.5 were carried out using the $z$ transformation of Fisher (1950).

\section{Results}

It has previously been shown that there is selection favouring early onset of symptoms and age at death in recent compared with prior sibships of a kindred affected with Huntington's disease (Wendt, Landzettel, and Unterreiner, 1959; Wendt, Solth, and Landzettel, 1960/1961; Brackenridge, 1971a). The artifact of anticipation is thus produced. The effect of the number of generations between ascertainment and a sibship of interest in relation to sib-sib and parent-child correlations is shown in Table I. As the ages at onset and death of children and parents increase with the number of intervening generations there is a decrease in both types of correlation coefficient. Tests of heterogeneity revealed that sib-sib coefficients most probably arose from different populations $\left(\chi^{2}=80.53,3 \mathrm{df}, \mathrm{p}<0.001\right.$ for age at onset and $\chi^{2}=48.69, \mathrm{p}<0.001$ for age at death). The variation was less pronounced for the parent-child correlations; the heterogeneity was not significant with respect to age at onset $\left(\chi^{2}=6 \cdot 04\right.$, $\mathrm{p}>0 \cdot 1)$ but it was appreciable for age at death $\left(\chi^{2}=10 \cdot 89, \mathrm{p}<0.02\right)$.

In subsequent analyses the generations were pooled. The effects of sex on parent-child correlations are shown in Table II. All the coefficients obtained were significantly positive. In the case of age at onset, the coefficient for father-child pairs significantly exceeded $0.5(p<0.04)$. The correlation 
TABLE I

RELATION BETWEEN CORRELATION COEFFICIENTS AND THE NUMBER OF GENERATIONS FROM THE TIME OF ASCERTAINMENT

\begin{tabular}{|c|c|c|c|c|c|c|c|c|}
\hline \multirow{2}{*}{$\begin{array}{l}\text { No. of } \\
\text { Intervening } \\
\text { Generations }\end{array}$} & \multicolumn{2}{|c|}{ Sib-Sib Correlations* } & \multicolumn{2}{|c|}{ Parent-Child Correlations } & \multicolumn{2}{|c|}{ Mean Ages of Children } & \multicolumn{2}{|c|}{ Mean Ages of Parents } \\
\hline & Age at Onset & Age at Death & Age at Onset & Age at Death & Age at Onset & Age at Death & Age at Onset & Age at Death \\
\hline 0 & $\begin{array}{c}0.817 \pm 0.035 \\
(61,134)\end{array}$ & $\begin{array}{c}0.896 \pm 0.039 \\
(22,50)\end{array}$ & $0.571 \pm 0.063$ & $\begin{array}{c}0.686 \pm 0.068 \\
(60)\end{array}$ & $20 \cdot 1 \pm 1 \cdot 2$ & $39 \cdot 8 \pm 2 \cdot 5$ & $34.4 \pm 0.9$ & $53 \cdot 4 \pm 2 \cdot 2$ \\
\hline 1 & $\begin{array}{c}0.509 \pm 0.060 \\
(123,304)\end{array}$ & $\begin{array}{c}0.673 \pm 0.054 \\
(72,177)\end{array}$ & $\begin{array}{c}0.457 \pm 0.047 \\
(284)\end{array}$ & $\begin{array}{c}0.488 \pm 0.053 \\
(208)\end{array}$ & $31 \cdot 3 \pm 0.6$ & $47 \cdot 9 \pm 0 \cdot 9$ & $40.2 \pm 0.6$ & $56.6 \pm 0.9$ \\
\hline 2 & $\begin{array}{c}0.264 \pm 0 \cdot 111 \\
(109,297)\end{array}$ & $\begin{array}{c}0.449 \pm 0.062 \\
(133,378)\end{array}$ & $\begin{array}{c}0.456 \pm 0.060 \\
(177)\end{array}$ & $\begin{array}{c}0.416 \pm 0.046 \\
(327)\end{array}$ & $37 \cdot 2 \pm 0 \cdot 8$ & $52 \cdot 4 \pm 0 \cdot 7$ & $44 \cdot 4 \pm 0.8$ & $58 \cdot 8 \pm 0.7$ \\
\hline $3-7$ & $\begin{array}{c}0 \cdot 185 \pm 0 \cdot 162 \\
(33,95)\end{array}$ & $\begin{array}{c}0.479 \pm 0.067 \\
(90,262)\end{array}$ & $\begin{array}{c}0.210 \pm 0.082 \\
(46)\end{array}$ & $\begin{array}{c}0.363 \pm 0.055 \\
(253)\end{array}$ & $41 \cdot 2 \pm 1 \cdot 8$ & $55.6 \pm 0.9$ & $43 \cdot 7 \pm 1 \cdot 4$ & $58.9 \pm 0.9$ \\
\hline
\end{tabular}

* Values in parentheses denote number of sibships and number of sibs, respectively.

+ Values in parentheses denote number of pairs.

coefficient between fathers and sons for age at death was appreciably lower than $0.5(p<0.005)$. So low was its magnitude that it differed significantly from those for mother-son $(p<0.01)$ and father-daughter pairs $(p<0.03)$. There was a tendency for coefficients between mothers and sons to exceed those between mothers and daughters for age at onset as well as age at death $(0.1<\mathrm{p}>0.05$ in each case).

Table III records results obtained for sib-sib correlations, all of which were significantly positive. In the case of onset age, correlation coefficients between the following sibs were higher than 0.5 : sisters of affected fathers $(p<0.001)$, sibs of affected fathers $(p>0.001)$, and sibs of affected parents $(p<$ 0.01 ). For age at death, sib-sib coefficients derived from affected fathers $(p<0.04)$ and parents $(p<$ 0.001 ) exceeded 0.5 . The degree of resemblance between sisters of affected fathers was significantly greater with respect to onset age than between sisters $(p<0.002)$ or brothers $(p<0.04)$ of affected mothers. As a result the intra-class correlations between all paternal sibs exceeded that between all maternal sibs $(p<0.03)$ for onset age.

The effects of the major neurological sign in affected offspring on sib-sib and parent-child cor- relations was next examined. Table IV indicates that all except the coefficients between sibs displaying rigidity and hypokinesia were significant in magnitude. Two parent-child correlation coefficients were higher than 0.5 : these were for age at onset of choreic subjects $(p<0.02)$ and age at death of rigid subjects $(p<0.03)$. In addition the correlation between the age at onset of choreic subjects and their parents was appreciably stronger $(\mathrm{p}<0.01)$ than that between hypertonic subjects and their parents. The converse was true with respect to age at death, the coefficient between rigid patients and their parents being higher $(p<0.02)$ than for choreics.

With regard to the order of appearance of symptoms, the results in Table $\mathrm{V}$ demonstrate that all coefficients were significantly positive except for those derived from correlations between sibs in whom neurological signs succeeded psychiatric symptoms. The correlation coefficient for age at death between sibs in whom the onset of neurological and psychiatric symptoms could not be distinguished was greater than $0.5(\mathrm{p}<0.001)$. There was no significant heterogeneity among sib-sib or parent-child coefficients derived from subjects grouped according to their clinical history.

TABLE II

PARENT-CHILD CORRELATION COEFFICIENTS*

\begin{tabular}{|c|c|c|c|c|c|c|}
\hline & \multicolumn{2}{|c|}{ Father } & \multicolumn{2}{|c|}{ Mother } & \multicolumn{2}{|c|}{ Parent } \\
\hline & Age at Onset & Age at Death & Age at Onset & Age at Death & Age at Onset & Age at Death \\
\hline Son & $\begin{array}{c}0.575 \pm 0.053 \\
(159)\end{array}$ & $\begin{array}{c}0.360 \pm 0.054 \\
(262)\end{array}$ & $\begin{array}{c}0.613 \pm 0.053 \\
(139)\end{array}$ & $\begin{array}{c}0.577 \pm 0.050 \\
(189)\end{array}$ & $\begin{array}{c}0.573 \pm 0.039 \\
(298)\end{array}$ & $\begin{array}{c}0.440 \pm 0.038 \\
(451)\end{array}$ \\
\hline Daughter & $\begin{array}{c}0.601 \pm 0.048 \\
(181)\end{array}$ & $\begin{array}{c}0.531 \pm 0.049 \\
(211)\end{array}$ & $\begin{array}{c}0.449 \pm 0.067 \\
(143)\end{array}$ & $\begin{array}{c}0.424 \pm 0.060 \\
(186)\end{array}$ & $\begin{array}{c}0.499 \pm 0.042 \\
(324)\end{array}$ & $\begin{array}{c}0.471 \pm 0.039 \\
(397)\end{array}$ \\
\hline Child & $\begin{array}{c}0.582 \pm 0.036 \\
(340)\end{array}$ & $\begin{array}{c}0.442 \pm 0.037 \\
(473)\end{array}$ & $\begin{array}{c}0.533 \pm 0.043 \\
(282)\end{array}$ & $\begin{array}{c}0.492 \pm 0.039 \\
(375)\end{array}$ & $\begin{array}{c}0.531 \pm 0.029 \\
(622)\end{array}$ & $\begin{array}{c}0.456 \pm 0.027 \\
(848)\end{array}$ \\
\hline
\end{tabular}

* Values in parentheses denote number of pairs. 
TABLE III

SIB-SIB CORRELATION COEFFICIENTS*

\begin{tabular}{|c|c|c|c|c|c|c|}
\hline & \multicolumn{2}{|c|}{ Offspring of Affected Fathers } & \multicolumn{2}{|c|}{ Offspring of Affected Mothers } & \multicolumn{2}{|c|}{ Offspring of Affected Parents } \\
\hline & Age at Onset & Age at Death & Age at Onset & Age at Death & Age at Onset & Age at Death \\
\hline Brother-Brother & $\begin{array}{c}0.531 \pm 0.082 \\
(60,141)\end{array}$ & $\begin{array}{c}0.598 \pm 0.065 \\
(73,174)\end{array}$ & $\begin{array}{c}0 \cdot 449 \pm 0 \cdot 102 \\
(51,116)\end{array}$ & $\begin{array}{c}0.481 \pm 0 \cdot 084 \\
\quad(57,137)\end{array}$ & $\begin{array}{c}0.529 \pm 0.060 \\
(115,266)\end{array}$ & $\begin{array}{c}0.541 \pm 0.049 \\
(137,325)\end{array}$ \\
\hline Sister-Sister & $\begin{array}{c}0.698 \pm 0.056 \\
(64,146)\end{array}$ & $\begin{array}{c}0.492 \pm 0.077 \\
(63,144)\end{array}$ & $\begin{array}{c}0 \cdot 270 \pm 0.122 \\
(55,116)\end{array}$ & $\begin{array}{c}0.434 \pm 0.100 \\
(44,110)\end{array}$ & $\begin{array}{c}0.566 \pm 0.053 \\
(124,274)\end{array}$ & $\begin{array}{c}0.506 \pm 0.061 \\
(155,275)\end{array}$ \\
\hline Sib-Sib & $\begin{array}{c}0.630 \pm 0.039 \\
(180,447)\end{array}$ & $\begin{array}{c}0.590 \pm 0.043 \\
(178,476)\end{array}$ & $\begin{array}{c}0.470 \pm 0.061 \\
(133,350)\end{array}$ & $\begin{array}{c}0.516 \pm 0.059 \\
(120,341)\end{array}$ & $\begin{array}{c}0.587 \pm 0.032 \\
(327,831)\end{array}$ & $\begin{array}{c}0.580 \pm 0.016 \\
(317,867)\end{array}$ \\
\hline
\end{tabular}

* Values in parentheses denote number of sibships and number of sibs respectively.

TABLE IV

RELATION BETWEEN CORRELATION COEFFICIENTS AND PREDOMINANT NEUROLOGICAL SIGNS

\begin{tabular}{l|c|c|c|c}
\hline \multirow{2}{*}{ Neurological Sign } & \multicolumn{2}{|c|}{ Sib-Sib Correlations* } & \multicolumn{2}{c}{ Parent-Child Correlationst } \\
\cline { 2 - 5 } & Age at Onset & Age at Death & Age at Onset & Age at Death \\
\hline Chorea & $\begin{array}{c}0.497 \pm 0.081 \\
(69,163)\end{array}$ & $\begin{array}{c}0.605 \pm 0.088 \\
(39,90)\end{array}$ & $\begin{array}{c}0.630 \pm 0.047 \\
(168)\end{array}$ & $\begin{array}{c}0.515 \pm 0.061 \\
(145)\end{array}$ \\
\hline Rigidity & $\begin{array}{c}0.235 \pm 0.188 \\
(25,53)\end{array}$ & $\begin{array}{c}0.609 \pm 0.561 \\
(9,19)\end{array}$ & $\begin{array}{c}0.303 \pm 0.118 \\
(59)\end{array}$ & $\begin{array}{c}0.739 \pm 0.078 \\
(34)\end{array}$ \\
\hline
\end{tabular}

* Values in parentheses denote number of sibships and number of sibs, respectively.

t Values in parentheses denote number of pairs.

TABLE V

RELATION BETWEEN CORRELATION COEFFICIENTS AND ORDER OF APPEARANCE OF SYMPTOMS

\begin{tabular}{l|c|c|c|c}
\hline \multicolumn{1}{c|}{ Order of Symptoms } & \multicolumn{2}{|c|}{ Sib-Sib Correlations* } & \multicolumn{2}{|c}{ Parent-Child Correlationst } \\
\cline { 2 - 4 } & Age at Onset & Age at Death & Age at Onset & Age at Death \\
\hline Neurological before psychiatric & $\begin{array}{c}0.773 \pm 0.288 \\
(23,49)\end{array}$ & $\begin{array}{c}0.565 \pm 0.142 \\
(18,40)\end{array}$ & $\begin{array}{c}0.502 \pm 0.095 \\
(62)\end{array}$ & $\begin{array}{c}0.607 \pm 0.072 \\
(77)\end{array}$ \\
\hline Neurological and psychiatric coincident & $\begin{array}{c}0.631 \pm 0.089 \\
(34,75)\end{array}$ & $\begin{array}{c}0.858 \pm 0.059 \\
(14,28)\end{array}$ & $\begin{array}{c}0.582 \pm 0.066 \\
(100)\end{array}$ & $\begin{array}{c}0.537 \pm 0.100 \\
(51)\end{array}$ \\
\hline Neurological after psychiatric & $\begin{array}{c}0.367 \pm 0.206 \\
(16,38)\end{array}$ & $\begin{array}{c}0.342 \pm 0.230 \\
(10,22)\end{array}$ & $\begin{array}{c}0.625 \pm 0.076 \\
(65)\end{array}$ & $\begin{array}{c}0.480 \pm 0.108 \\
(51)\end{array}$ \\
\hline
\end{tabular}

* Values in parentheses denote number of sibships and number of sibs, respectively.

t Values in parentheses denote number of pairs.

\section{Discussion}

Associated with the different bivariate distributions of the age at onset and age at death of parents and children in the generations preceding the time of ascertainment, there is a considerable variation in intraclass and interclass correlation coefficients. For recently recorded sibships, a further source of bias supplements the effect of anticipation. This arises from neglecting cases of late onset because they were unaffected when their sibships were examined. Bell (1942) recognized this possibility when she obtained a sib-sib correlation coefficient of 0.465 for the age at onset of $442 \mathrm{sib}$ pairs of Huntington's disease described in the literature up to 1932. This is appreciably different from the value of 0.587 reported in Table III and each is much higher than the coefficient of 0.28 calculated by Reed and Chandler (1958) for completely ascertained cases in Michigan. The sib-sib coefficient of 0.47 for age at death found by these authors is closer to the values of 0.521 , found by Bell (1942), and 0.590 in Table III.

In an earlier study (Brackenridge, 1972) a tendency was noted for the correlation between ages at onset of half-sibs of a common affected father to exceed that between half-sibs of a common affected mother. In the present investigation, this became significant for full sisters and sibs, but not for brothers. The other intraclass correlation difference involving a parental sex effect was related 
to this latter result, the degree of resemblance between the onset ages of sisters born to affected fathers exceeding that between brothers born to affected mothers. This was also the only example of a difference between two sib-sib correlations in which the offspring were of opposite sex. The underlying cause may relate to the tendency for daughters of affected fathers to display symptoms at an earlier age than sons of affected mothers (Brackenridge, 1971a).

With respect to affected parents and offspring, Bell (1942) recorded an onset age correlation of 0.593 from 153 pairs and Panse (1942) a value of 0.66 from 103 pairs, both of which are rather higher than the present result of 0.531 in Table II. The value of 0.472 which Bell obtained from 152 parent-child pairs for age at death is in good agreement with the figure of 0.456 reported here. The slightly longer life of sons of affected fathers compared with paternal daughters (Brackenridge, 1971a) could be a factor in the difference between the age at death correlation of sons of affected fathers and daughters of affected fathers. However such an explanation cannot account for the father-son and father-daughter difference in correlations of age at death because there is essentially no parental influence on the survival of affected male offspring.

In addition to the sex of the affected subject and of the transmitting parent, the order of appearance of clinical symptoms and the main neurological sign (choreo-athetosis or rigidity) were found to be significant determinants of age at onset and age at death (Brackenridge, 1971b). Because of the rarity of subjects with Huntington's disease presenting with hypokinesia and hypertonia (about $18 \%$ of all cases) few sibships have more than one such member. The number available for correlation estimates was therefore not high in the present study. Significant coefficients were nevertheless obtained for parent-child correlations. An apparent anomaly requiring comment is that the interclass age at onset correlation is appreciably stronger for choreic than for rigid subjects whereas the age at death correlation is stronger for rigid than for choreic subjects. A probable explanation is that the date of decease is obviously much easier to specify than the age at onset of symptoms which are earlier and tend to be more insidious in the Westphal and juvenile variants than in classical cases (Bittenbender and Quadfasel, 1962; Bruyn, 1968; Brackenridge, 1971b). There is consequently a greater uncertainty associated with correlations of age at onset; this is confirmed by the greater standard error of intraclass correlations for rigid subjects in Table IV. This reasoning does not necessarily apply to choreic subjects, who die at a later age (Brackenridge, 1971b) and are thus more liable to morbidity factors not directly associated with Huntington's disease.

An interesting aspect of the relation between correlation coefficients and the order of appearance of symptoms is that sib-sib coefficients are higher when neurological signs precede or accompany psychiatric symptoms than when they succeed them. A possible explanation is that when chorea or rigidity appear relatively early in the course of the disorder fitness for parenthood is likely to be lower than when psychiatric symptoms present first. Subjects of the former type are therefore more likely to be represented in later than earlier generations of a kindred and thereby give rise to high correlation coefficients as indicated in Table I.

Excluding the generation-dependent results in Table I, 28 intraclass and 28 interclass correlation coefficients were determined; about 3 of these could be significant by chance factors alone. Only 1 coefficient (age at death between rigid sibs) was uninformative, being indistinguishable from $0,0.5$ and $1 \cdot 0$. One (age at onset between sibs showing neurological symptoms first) was not significantly different from 0.5 or 1.0 , while another (father-son correlations for age at death) differed significantly from zero or 0.5 ; each lay between these limits. Three could not be distinguished from zero or 0.5 , and 9 were significantly higher than 0.5 but less than unity. The remaining 41 coefficients (17 sibsib and 24 parent-child) were all greater than zero, less than unity and could not be differentiated from 0.5 ; these clearly formed the major group of values. Any hypothesis requiring a correlation coefficient of this magnitude would therefore account for most of the present results.

Haldane (1941) has shown that if a disease is determined by a single gene and a considerable number of independent modifiers, then the sib-sib and parent-child correlation coefficients will be about 0.5 . Values nearer to one would be expected from the operation of several independent genes, each with a characteristic age at onset or age at death distribution. The $6 \mathrm{sib}-\mathrm{sib}$ and 3 parent-child coefficients exceeding 0.5 but less than unity could arise in the latter way or, with the single coefficient of less than 0.5 , represent the effects of errors in assessing the age at onset, non-hereditary factors producing an earlier age at death and random fluctuations due to sampling bias.

If environmental factors such as pregnancy also influence the time of onset of symptoms, the correlations will be reduced. The present results suggest that such factors play a minor role because 
only 4 of the 56 coefficients were compatible with a zero correlation and even these were also indistinguishable from 0.5 . It could be argued that non-genetic effects reduce a theoretical coefficient of 1 to about $0 \cdot 5$. A perfect correlation would be expected only if each of several genes brings on the disorder at exactly the same age (Harris and Smith, 1947/1949). This is clearly not the case in Huntington's disease in which a wide range of onset ages is found. However it is difficult to refute the possibility that environmental modification spreads the various distinct onset ages into a tolerably normal distribution, particularly if the frequencies of the genes are similar and the onset ages they determine are well separated.

Harris and Smith (1947/1949) have pointed out that an intraclass onset correlation of about 0.5 may be accounted for in 2 other ways. (1) A single main gene operates with several modifying genes to produce an essentially normal age distribution, or (2) a number of mimic genes operate, each having its own age of onset distribution.

In principle the alternatives can be distinguished by analysing the nature of the observed distribution. Burch (1968) has done this for several population samples and has concluded that discontinuities exist at similar ages in each curve. This would favour mechanism (2) which can be readily accommodated with the hypothesis of environmental modification of the action of several independent genes specifying characteristic ages at onset. However, on the basis of the present results alone, it is not possible to choose between the various mechanisms which yield a correlation of 0.5 .

\section{Summary}

Parent-child and sib-sib correlation coefficients have been calculated with respect to the age at onset and the age at death of subjects with Huntington's disease. Values were strongly dependent on the number of generations between a given sibship and the time of ascertainment. Sex of subject and of the transmitting parent exercised no consistent effect on the correlations. The influence of the predominant neurological sign (choreo-athetosis or rigidity) and of the order of appearance of symptoms were also examined but no obvious pattern emerged.

Most of the correlation coefficients did not differ significantly from $0 \cdot 5$. This is consistent with a number of genetic mechanisms involving the action of a single main gene with several modifiers, a number of mimic genes each with its own age distribution or environmental factors superimposed on different rare genes.

This work was supported by a grant from the National Health and Medical Research Council of Australia.

\section{REFERENCES}

Bell, J. (1934). Nervous disease and muscular dystrophies. Part 1. Huntington's chorea. In The Treasury of Human Inheritance, ed. by R. A. Fisher and L. S. Penrose. Cambridge University Press, London.

Bell, J. (1942). On the age of onset and age at death in hereditary muscular dystrophy with some observations bearing on the question of antedating. Annals of Eugenics, 11, 272-289.

Bittenbender, J. B. and Quadfasel, F. A. (1962). Rigid and akinetic forms of Huntington's chorea. Archives of Neurology, 7, 275-288.

Brackenridge, C. J. (1971a). A genetic and statistical study of some sex-related factors in Huntington's disease. Clinical Genetics, 2, 267-286.

Brackenridge, C. J. (1971b). The relation of type of initial symptoms and line of transmission to ages at onset and death in Huntington's disease. Clinical Genetics, 2, 287-297.

Brackenridge, C. J. (1972). A statistical study of half-sibships born to parents affected with Huntington's disease. Fournal of Medical Genetics, 9, 17-22.

Bruyn, G. W. (1968). Huntington's chorea. Historical, clinical and laboratory synopsis. In Handbook of Clinical Neurology, vol. 6, pp. 298-378, ed. by P. J. Vinken and G. W. Bruyn. NorthHolland Publishing Co., Amsterdam.

Burch, P. R. J. (1968). Huntington's chorea. Age at onset in relation to aetiology and pathogenesis. In Handbook of Clinical Neurology, vol. 6, pp. 379-398, ed. by P. J. Vinken and G. W. Bruyn. North-Holland Publishing Co., Amsterdam.

Fieller, E. C. and Smith, C. A. B. (1951/1952). Note on the analysis of variance and intraclass correlations. Annals of Eugenics, 16, 97-104.

Fisher, R. A. (1950). Statistical Methods for Research Workers, 11th ed., pp. 192-204. Oliver and Boyd, Edinburgh.

Haldane, J. B. S. (1941). The relative importance of principal and modifying genes in determining some human diseases. Fournal of Genetics, 41, 149-157.

Harris, H. and Smith, C. A. B. (1947/1949). The sib-sib age at onset correlation among individuals suffering from a hereditary syndrome produced by more than one gene. Annals of Eugenics, 14, 309-318.

Panse, F. (1942). Der Erbchorea, eine klinisch-genetische Studie. In Sammlung Psychiatrischer und Neurologischer Einzeldarstellung, vol. 18. Thieme, Berlin.

Penrose, L. S. (1948). The problem of anticipation in pedigrees of dystrophia myotonica. Annals of Eugenics, 14, 125-132.

Reed, T. E. and Chandler, J. H. (1958). Huntington's chorea in Michigan. I. Demography and genetics. American fournal of Human Genetics, 10, 210-225.

Smith, C. A. B. $(1956 / 1957)$. On the estimation of intraclass correlation. Annals of Human Genetics, 21, 363-373.

Wendt, G. G., Landzettel, H. J., and Unterreiner, L. (1959). Das Erkrankungsalter bei der Huntingtonschen Chorea. Acta Genetica et Statistica Medica, 9, 18-31.

Wendt, G. G., Solth, K., and Landzettel, H. J. (1960/1961). Kinderzahl, Erkrankungsalter und Sterbealter bei der Huntingtonschen Chorea. Anthropologischer Anzeiger, 24, 299-309. 
Sources and Details of the Material

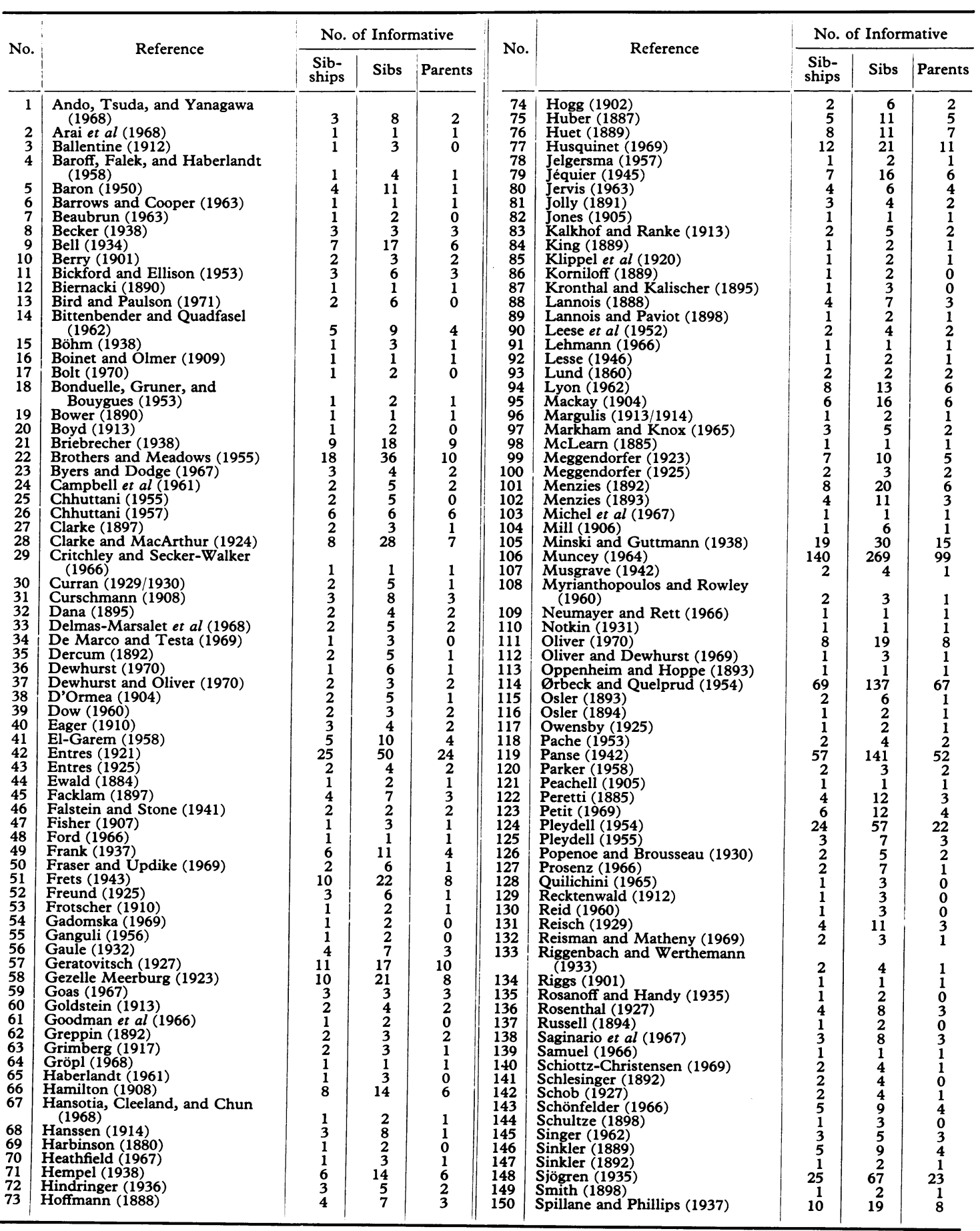


Appendix I-continued

\begin{tabular}{|c|c|c|c|c|c|c|c|c|c|}
\hline \multirow{2}{*}{ No. } & \multirow{2}{*}{ Reference } & \multicolumn{3}{|c|}{ No. of Informative } & \multirow{2}{*}{ No. } & \multirow{2}{*}{ Reference } & \multicolumn{3}{|c|}{ No. of Informative } \\
\hline & & $\begin{array}{l}\text { Sib- } \\
\text { ships }\end{array}$ & Sibs & Parents & & & $\begin{array}{l}\text { Sib- } \\
\text { ships }\end{array}$ & Sibs & Parents \\
\hline \multirow[t]{2}{*}{$\begin{array}{l}151 \\
152 \\
153 \\
154 \\
155 \\
156 \\
157 \\
158 \\
159 \\
160\end{array}$} & \multirow[t]{2}{*}{$\begin{array}{l}\text { Stevens and Parsonage (1969) } \\
\text { Stone (1932) } \\
\text { Stone and Falstein (1939) } \\
\text { Suckling (1889) } \\
\text { Sumner (1962) } \\
\text { Tay (1970) } \\
\text { Tibor (1918) } \\
\text { Tridon et al (1964) } \\
\text { Tsuang (1969) } \\
\text { Tyszkiewicz (1960) }\end{array}$} & \multirow[t]{2}{*}{$\begin{array}{l}2 \\
1 \\
8 \\
2 \\
1 \\
2 \\
1 \\
1 \\
4 \\
1\end{array}$} & \multirow[t]{2}{*}{$\begin{array}{r}4 \\
4 \\
16 \\
3 \\
4 \\
4 \\
3 \\
1 \\
7 \\
7 \\
2\end{array}$} & \multirow[t]{2}{*}{$\begin{array}{l}2 \\
0 \\
6 \\
2 \\
0 \\
2 \\
1 \\
1 \\
4 \\
0\end{array}$} & \multirow[t]{2}{*}{$\begin{array}{l}161 \\
162 \\
163 \\
164 \\
165 \\
166 \\
167\end{array}$} & $\begin{array}{l}\text { Wechsler (1920) } \\
\text { Werner and Folk (1968) } \\
\text { West (1884) } \\
\text { Weyrauch (1905) } \\
\text { Worster-Drought and Allen } \\
\text { (1929) } \\
\text { Zacher (1888) } \\
\text { Zolliker (1949) }\end{array}$ & $\begin{array}{l}1 \\
1 \\
3 \\
3 \\
5 \\
1 \\
2\end{array}$ & $\begin{array}{l}1 \\
2 \\
4 \\
7 \\
9 \\
9 \\
2\end{array}$ & $\begin{array}{l}1 \\
1 \\
3 \\
2 \\
3 \\
0 \\
2\end{array}$ \\
\hline & & & & & & Total & 814 & 1671 & 653 \\
\hline
\end{tabular}

\section{Appendix II \\ Ages at Onset and Death in Sibs and Parents}

TABLE A

AGE AT ONSET IN SIBS

\begin{tabular}{|c|c|c|c|c|c|c|c|c|c|c|c|c|c|c|c|c|c|c|c|}
\hline \multirow[b]{2}{*}{ Sex } & \multicolumn{16}{|c|}{ Age at Onset } & \multirow[b]{2}{*}{ Total } & \multirow[b]{2}{*}{ Mean } & \multirow[b]{2}{*}{ SE } \\
\hline & $I$ & in & $\stackrel{ \pm}{\vdots}$ & $\frac{9}{1}$ & $\begin{array}{l}\text { ন্ } \\
\text { d্ }\end{array}$ & $\begin{array}{l}\text { ஸे } \\
\text { ஸे }\end{array}$ & 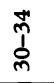 & $\begin{array}{l}\text { în } \\
\text { n̂m }\end{array}$ & $\underset{j}{7}$ & $\underset{8}{9}$ & $\begin{array}{l}\text { in } \\
\text { 1े } \\
\text { గn }\end{array}$ & $\begin{array}{l}\text { ⿵ิ } \\
\text { ஸ̂ } \\
\text { n̂n }\end{array}$ & $\begin{array}{l}\text { Dै } \\
1 \\
0 \\
0\end{array}$ & $\begin{array}{l}0 \\
1 \\
6 \\
0\end{array}$ & i্ & $\begin{array}{l}\stackrel{9}{1} \\
\mathfrak{n}\end{array}$ & & & \\
\hline Males & 11 & 20 & 17 & 25 & 44 & 62 & 86 & 64 & 92 & 27 & 31 & 14 & 11 & 1 & 1 & 1 & 507 & 33.07 & 0.59 \\
\hline Females & 11 & 27 & 26 & 24 & 40 & 63 & 88 & 67 & 66 & 48 & 41 & 5 & 8 & 2 & 0 & 1 & 517 & $32 \cdot 32$ & 0.59 \\
\hline$\overline{\text { Both }}$ & 22 & 47 & 43 & 49 & 84 & 125 & 174 & 131 & 158 & 75 & 72 & 19 & 19 & 3 & 1 & 2 & 1024 & 32.69 & 0.42 \\
\hline
\end{tabular}

TABLE B

AGE AT DEATH IN SIBS

\begin{tabular}{|c|c|c|c|c|c|c|c|c|c|c|c|c|c|c|c|c|c|c|c|c|c|}
\hline \multirow[b]{2}{*}{ Sex } & \multicolumn{18}{|c|}{ Age at Death } & \multirow[b]{2}{*}{ Total } & \multirow[b]{2}{*}{ Mean } & \multirow[b]{2}{*}{ SE } \\
\hline & in & $\stackrel{\Xi}{\grave{I}}$ & $\begin{array}{l}\stackrel{a}{1} \\
\stackrel{n}{n} \\
\end{array}$ & $\begin{array}{l}\text { İ } \\
\text { d̦ }\end{array}$ & $\begin{array}{l}\text { సิ } \\
1 \\
\text { ஸे } \\
\end{array}$ & $\begin{array}{l}\tilde{m} \\
\hat{\jmath} \\
\tilde{m}\end{array}$ & $\begin{array}{l}\tilde{m} \\
\tilde{n} \\
\tilde{n}\end{array}$ & $\begin{array}{l}* \\
1 \\
0 \\
0\end{array}$ & $\begin{array}{l}9 \\
1 \\
5\end{array}$ & $\begin{array}{l}\text { ஸे } \\
\text { ஸे } \\
\text { กิ }\end{array}$ & î & $\begin{array}{l} \pm \\
1 \\
1 \\
8\end{array}$ & $\begin{array}{l}8 \\
0 \\
1 \\
0 \\
\end{array}$ & $\begin{array}{l}\pi \\
\vdots \\
0\end{array}$ & 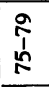 & $\begin{array}{l}\infty \\
0 \\
0 \\
0\end{array}$ & $\begin{array}{l}\infty \\
0 \\
1 \\
\infty \\
\infty\end{array}$ & 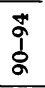 & & & \\
\hline Males & 1 & 3 & 10 & 8 & 14 & 23 & 40 & 79 & 86 & 74 & 71 & 61 & 34 & 38 & 19 & 20 & 6 & 3 & 590 & $52 \cdot 32$ & 0.62 \\
\hline Females & 3 & 5 & 7 & $\overline{6}$ & $\overline{17}$ & 23 & 45 & 65 & 69 & 81 & 53 & 43 & 32 & 32 & 20 & 11 & 10 & 2 & 524 & 51.43 & 0.68 \\
\hline Both & 4 & 8 & 17 & 14 & $\overline{31}$ & $\overline{46}$ & 85 & 144 & 155 & 155 & 124 & 104 & $\overline{66}$ & 70 & 39 & 31 & 16 & 5 & 1114 & 51.90 & 0.46 \\
\hline
\end{tabular}

TABLE C

AGE AT ONSET IN PARENTS

\begin{tabular}{|c|c|c|c|c|c|c|c|c|c|c|c|c|c|c|c|c|c|c|}
\hline \multirow[b]{2}{*}{ Sex } & \multicolumn{15}{|c|}{ Age at Onset } & \multirow[b]{2}{*}{ Total } & \multirow[b]{2}{*}{ Mean } & \multirow[b]{2}{*}{ SE } \\
\hline & in & $\stackrel{+}{\grave{T}}$ & $\stackrel{a}{\mathfrak{1}}$ & 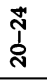 & ๙ิ & 亗 & $\begin{array}{l}\text { î } \\
\text { ñ } \\
\text { ñ }\end{array}$ & $\underset{7}{\$}$ & $\begin{array}{l}8 \\
1 \\
4\end{array}$ & ஸ્ & 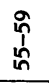 & $\begin{array}{l}\text { J } \\
0 \\
0\end{array}$ & $\begin{array}{l}8 \\
1 \\
10\end{array}$ & 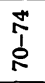 & $\begin{array}{l}\stackrel{9}{1} \\
1 \\
n \\
\end{array}$ & & & \\
\hline Males & 0 & 0 & 1 & 5 & 22 & 25 & 23 & 55 & 19 & 20 & 8 & 8 & 4 & 1 & 1 & 192 & 40.91 & 0.76 \\
\hline Females & 1 & 1 & 2 & 6 & 21 & 29 & 24 & 30 & 11 & 17 & 7 & 10 & 3 & 1 & 0 & 162 & $39 \cdot 14$ & 0.92 \\
\hline Both & 1 & 0 & 3 & 11 & 43 & 54 & 47 & 85 & 30 & 37 & 15 & 18 & 7 & 2 & 1 & 354 & $40 \cdot 10$ & 0.59 \\
\hline
\end{tabular}


TABLE D

AGE AT DEATH IN PARENTS

\begin{tabular}{|c|c|c|c|c|c|c|c|c|c|c|c|c|c|c|c|c|c|c|c|}
\hline \multirow[b]{2}{*}{ Sex } & \multicolumn{16}{|c|}{ Age at Death } & \multirow[b]{2}{*}{ Total } & \multirow[b]{2}{*}{ Mean } & \multirow[b]{2}{*}{ SE } \\
\hline & $\begin{array}{l}\text { İ } \\
\text { İ }\end{array}$ & $\begin{array}{l}\text { సิ } \\
\text { ஸ̂ }\end{array}$ & 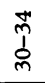 & $\begin{array}{c}\hat{m} \\
\hat{n}\end{array}$ & 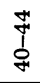 & \begin{tabular}{l}
9 \\
\multirow{2}{*}{}
\end{tabular} & 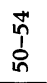 & $\begin{array}{l}\text { in } \\
\text { ñ } \\
\text { nn }\end{array}$ & $\begin{array}{l}: 0 \\
1 \\
1 \\
8\end{array}$ & $\begin{array}{l}9 \\
1 \\
1 \\
0\end{array}$ & $\stackrel{⿱}{T}$ & $\begin{array}{l}\mathfrak{i} \\
\mathfrak{1} \\
\kappa\end{array}$ & $\begin{array}{l}+ \\
\infty \\
1 \\
0\end{array}$ & $\begin{array}{l}\infty \\
\infty \\
1 \\
\infty \\
\infty\end{array}$ & $\begin{array}{l}\text { ò } \\
\text { ò } \\
8\end{array}$ & 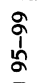 & & & \\
\hline Males & 1 & 1 & 8 & 5 & 26 & 31 & 36 & 34 & 33 & 22 & 25 & 12 & 9 & 5 & 2 & 1 & 251 & $57 \cdot 83$ & 0.85 \\
\hline Females & 0 & 5 & 3 & 14 & 19 & 24 & 31 & 21 & 23 & 12 & 19 & 13 & 7 & 5 & 3 & 0 & 199 & 56.93 & 1.04 \\
\hline Both & 1 & 6 & 11 & 19 & 45 & 55 & 67 & 55 & 56 & 34 & 44 & 25 & 16 & 10 & 5 & 1 & 450 & $57 \cdot 44$ & 0.66 \\
\hline
\end{tabular}

\section{Appendix III}

\section{Source References}

Ando, H., Tsuda, M., and Yanagawa, T. (1968). A case of 'rigid form' observed in a Huntington-chorea family. Clinical Neurology (Tokyo), 8, 185-190.

Arai, Y., Goto, A., Majima, T., Murofushi, K., and Narabayashi, $H$. (1968). Two cases of Huntington's chorea. Clinical and neuropathological studies of a typical and an atypical form in a family. Clinical Neurology (Tokyo), 8, 635-642.

Ballentine, E. P. (1912). Review of six cases of hereditary chorea. New York State fournal of Medicine, 12, 644-647.

Baroff, G. S., Falek, A., and Haberlandt, W. (1958). Impairment of psychomotor function in the early diagnosis of Huntington's chorea. Weiner Zeitschrift für Nervenheilkunde und deren Grenzgebiete, 15, 28-37.

Baron, G. (1950). Contribution à l'Étude Clinique et Génétique des Chorées Chroniques Progressives Familiales Maladie de Huntington et États Huntingtonniers. Thesis, Faculty of Medicine, Paris.

Barrows, H. S. and Cooper, W. C. (1963). Rigidity as a disease form of Huntington's disease. Bulletin of the Los Angeles Neurological Society, 28, 144-147.

Beaubrun, M. H. (1963). Huntington's chorea in Trinidad. West Indian Medical fournal, 12, 39-46.

Becker, G. (1938). Beitrag zur Klinik und Genealogie der Huntingtonschen Chorea. Allgemeine Zeitschrift für Psychiatrie, 107, 193232.

Bell, J. (1934). Nervous disease and muscular dystrophies. Part I. Huntington's chorea. In The Treasury of Human Inheritance, ed. by R. A. Fisher and L. S. Penrose. Cambridge University Press, London.

Berry, W. D. (1901). A contribution to the study of hereditary chorea. American fournal of Insanity, 57, 331-339.

Bickford, J. A. R. and Ellison, R. M. (1953). The high incidence of Huntington's chorea in the duchy of Cornwall. fournal of Mental Science, 99, 291-294.

Biernacki, E. (1890). Ein Fall von chronischer hereditärer Chorea. Berliner klinische Wochenschrift, 27, 485-489.

Bird, M. T. and Paulson, G. W. (1971). The rigid form of Huntington's chorea. Neurology (Minneapolis), 21, 271-276.

Bittenbender, J. B. and Quadfasel, F. A. (1962). Rigid and akinetic forms of Huntington's chorea. Archives of Neurology, 7, 275-288.

Böhm, J. (1938). Die Chorea-Huntington-Sippe Fellhauer. Dissertation, University of Heidelberg.

Boinet, E. and Olmer, J. (1909). Chorée héréditaire chronique. Revue Neurologique, 17, 662-664.

Bolt, J. M. W. (1970). Huntington's chorea in the west of Scotland. British fournal of Psychiatry, 116, 259-270.

Bonduelle, M., Gruner, J., and Bouygues, P. (1953). Chorée de Huntington avec paraplégie spasmodique: deux cas familiaux; étude anatomique, remarque sur les rélations de la surdité et des lésions de l'olive supérieure. Revue Neurologique, 88, 126-131.

Bower, J. L. (1890). Notes on some cases of chorea and tremor. fournal of Nervous and Mental Diseases, 15, 131-142.

Boyd, W. A. (1913). Hereditary chorea with report of a case. Boston Medical and Surgical fournal, 169, 680-684. Briebrecher, G. (1938). Chorea Huntington-Sippe. Dissertation,
University of Bonn.
Brothers, C. R. D. and Meadows, A. W. (1955). An investigation of Huntington's chorea in Victoria. Fournal of Mental Science, 101, 548-563.

Byers, R. K. and Dodge, J. A. (1967). Huntington's chorea in children. Report of four cases. Neurology (Minneapolis), 17, 587-596.

Campbell, A. M. G., Corner, B., Norman, R. M., and Urich, H. (1961). The rigid form of Huntington's disease. fournal of Neurology, Neurosurgery and Psychiatry, 24, 71-77.

Chhuttani, P. N. (1955). Huntington's chorea in the Punjab (India). Fournal of the Association of Physicians of India, 3, 40-45.

Chhuttani, P. N. (1957). Senile versus Huntington's chorea. Indian fournal of the Medical Sciences, 11, 827-828.

Clarke, J. M. (1897). On Huntington's chorea. Brain, 20, 22-34.

Clarke, C. K. and MacArthur, J. W. (1924). Four generations of hereditary chorea. Fournal of Heredity, 15, 303-306.

Critchley, E. M. R. and Secker-Walker, R. H. (1966). A deaf-mute with Huntington's chorea. fournal of Neurology, Neurosurgery and Psychiatry, 29, 181-183.

Curran, D. (1929/1930). Huntington's chorea without choreiform movements. Fournal of Neurology and Psychopathology, 10, 305-310.

Curschmann, H. (1908). Eine neue Chorea-Huntingtonfamilie. Deutsche Zeitschrift für Nervenheilkunde, 35, 293-305.

Dana, C. L. (1895). The pathology of hereditary chorea. Report of a case with autopsy; record of anomalies in a degenerate brain. fournal of Nervous and Mental Diseases, 20, 565-583.

Delmas-Marsalet, P., Bourgeois, M., Vital, C., and Fontanges, X. (1968). Formes rigides de la maladie de Huntington (étude d'une famille avec un cas anatomo-clinique). Revue Neurologique, 118, 273-283.

De Marco, P. and Testa, G. (1969). La forma infanto-prepuberale della corea di Huntington. Giornale di Psichiatria e di Neuropatologia, 97, 391-403.

Dercum, F. X. (1892). Adult chorea. International Clinics, 3, 292-297.

Dewhurst, K. (1970). Personality disorder in Huntington's disease. Psychiatria Clinica, 3, 221-229.

Dewhurst, K. and Oliver, J. (1970). Huntington's disease of young people. European Neurology, 3, 278-289.

D'Ormea, A. (1904). Una famiglia coreica. Riforma Medica, 20, 313-318.

Dow, D. S. (1960). Huntington's chorea; differentiated from Wilson's disease with report of unusual case. Rocky Mountain Medical fournal, 57, 44-50.

Eager, R. (1910). Notes on four cases of Huntington's chorea. fournal of Mental Science, 56, 506-509.

El-Garem, O. (1958). The first record of three families of Huntington's chorea in Egypt. Alexandria Medical fournal, 4, 364-376.

Entres, J. L. (1921). Zur Klinik und Vererbung der Huntington'schen Chorea (Monographien aus dem Gesamtgebiet der Neurologie und Psychiatrie, Heft 37). Springer-Verlag, Berlin.

Entres, J. L. (1925). Genealogische Studie zur Differentialdiagnose zwischen Wilsonscher Krankheit und Huntingtonscher Chorea. Zeitschrift für die gesamte Neurologie und Psychiatrie, 98, 497-509. 
Ewald, C. A. (1884). Zwei Fälle choreatischer Zwangsbewegungen mit ausgesprochener Heredität. Zeitschrift für Klinische Medizin, 7, 51-57.

Facklam, F. C. (1897). Beiträge zur Lehre vom Wesen der Huntington'schen Chorea. Archiv für Psychiatrie und Nervenkrankheiten, 30, 137-204.

Falstein, E. I. and Stone, T. T. (1941). Juvenile Huntington's chorea. Archives of Neurology and Psychiatry, 45, 151-155.

Fisher, E. D. (1907). Report of a case of Huntington's chorea in which four members of the family were affected. Fournal of Nervous and Mental Diseases, 34, 52.

Ford, F. R. (1966). Diseases of the Nervous System in Infancy, Childhood and Adolescence, 5th ed, p. 256. Charles C. Thomas, Springfield.

Frank, W. (1937). Untersuchungen über Chorea Huntington an Hand von 19 Fallen unter besonderer Berucksichtigung der Erblichkeit und der Frühsymptome. Psychiatrisch-neurologische Wochenschrift, 39, 51-58.

Fraser, L. A. and Updike, M. E. (1969). Huntington's chorea: a case investigation. Fournal of the Medical Society of New fersey, 66, 256-259.

Frets, G. P. (1943). De erfelijkheid bij 15 lijders aan chronische, progressieve chorea (Huntington), die in de jaren 1914-1941 in de psychiatrische inrichting 'Maasoord' verpleegd zijn. Genetica, 23, 465-528.

Freund, C. S. (1925). Zur Vererbung der Huntington'schen Chorea. Zeitschrift für die gesamte Neurologie und Psychiatrie, 99, 333-375.

Frotscher, R. (1910). Ein Beitrag zum Krankheitsbild der Chorea chronica progressiva. Archiv für Psychiatrie und Nervenkrankheiten, 47, 790-805.

Gadomska, B. (1969). Dziecieca postać plasawicy Huntingtona. Neurologia i Neurochirurgia Polska, 3, 351-354.

Ganguli, L. K. (1956). Procaineamide hydrochloride in Huntington's chorea. Fournal of the Indian Medical Association, 26, 274-275.

Gaule, A. (1932). Das Auftreten der Chorea Huntington in einer Familie der Nordostschweiz. Schweizer Archiv für Neurologie und Psychiatrie, 29, 90-112.

Geratovitsch, M. (1927). Über Erblichkeitsuntersuchungen bei der Huntington'schen Krankheit. Archiv für Psychiatrie und Nervenkrankheiten, 80, 513-535.

Gezelle Meerburg, G. F. (1923). Bijdrage, naar Aanleiding van een Anatomisch en Genealogisch Onderzoek tot de Kennis van de Chorea Huntingtonea. Thesis, University of Utrecht.

'Goas, J. Y. (1967). Contribution à l'Étude de la Chorée de Huntington. Thesis, Paris.

Goldstein, M. (1913). Ein kasuistischer Beitrag zur Chorea chronica hereditaria. Münchener medizinische Wochenschrift, 60, 1659-1662.

Goodman, R. M., Hall, C. L., Terango, L., Perrine, G. A., and Roberts, P. L. (1966). Huntington's chorea: a multidisciplinary study of affected parents and first generation. Archives of Neuro$\log y, 15,345-355$.

Greppin, L. (1892). Ueber einen Fall Huntington'scher Chorea. Archiv für Psychiatrie und Nervenkrankheiten, 24, 155-190.

Grimberg, L. (1917). Huntington's chorea. New York Medical fournal, 105, 160-161.

Gröpl, H. (1968). Chorea Huntington im Kindesalter. Zeitschrift für Kinderheilkunde, 103, 45-51.

Haberlandt, W. F. (1961). Klinisch-genetische Beobachtungen bei der Huntingtonschen Chorea. Arztliche Praxis, 13, 1225-1229.

Hamilton, A. S. (1908). A report of twenty-seven cases of chronic progressive chorea. American fournal of Insanity, 64, 403-475.

Hansotia, P., Cleeland, C. S., and Chun, R. W. M. (1968). Juvenile Huntington's chorea. Neurology (Minneapolis), 18, 217-224.

Hanssen, O. (1914). Den Saetesdalske chorea St. Viti. Medicinsk Revue, 31, 569-579.

Harbinson, A. (1880). Sclerosis of the nervous centres, mainly cerebral. Medical Press, 1, 123-125.

Heathfield, K. W. G. (1967). Huntington's chorea. Investigation into the prevalence of this disease in the area covered by the North East Metropolitan Regional Hospital Board. Brain, 90, 203-232.

Hempel, H. C. (1938). Ein Beitrag zur Huntingtonschen Erkrankung. Zeitschrift für die gesamte Neurologie und Psychiatrie, 160, 565-597.

Hindringer, P. (1936). Eine neue Chorea Huntington-Sippe mit einer kurzen Zusammenstellung des gesamten Schrifttums der letzten 15 fahre über Chorea Huntington. Thesis, University of Erlangen.
Hoffmann, J. (1888). Ueber Chorea chronica progressive (Huntington'sche Chorea, Chorea hereditaria). Virchows Archiv für pathologische Anatomie und Physiologie und für klinische Medizin, 111, 513-548.

Hogg, C. A. (1902). Two cases of Huntington's chorea, with a family history. Australasian Medical Gazette, 21, 400-404.

Huber, A. (1887). Chorea hereditaria der Erwachsenen (Huntington'sche Chorea). Virchows Archiv für pathologische Anatomie und Physiologie und für klinische Medizin, 108, 267-285.

Huet, E. (1889). De la Chorée Chronique. Thesis, University of Paris.

Husquinet, H. (1969). La chorée de Huntington dans quatre provinces Belges. In Rapports 67e Session, Congrès de Psychiatrie et de Neurologie de Langue Française, Brussels. Masson, Paris.

Jelgersma, H. C. (1957). Monozygotic twins with concordant Huntington's chorea and discordant hemiplegia. Folia Psychiatrica (Amsterdam), 60, 50-52.

Jéquier, M. (1945). La chorée de Huntington. Archiv der fulius Klaus-Stiftung für Vererbungsforschung, Sozialanthropologie und Rassenhygiene, 20, 77-202.

Jervis, G. A. (1963). Huntington's chorea in childhood. Archives of Neurology, 9, 244-257.

Jolly, F. (1891). Ueber Chorea hereditaria. Neurologische Zentralblatt, 10, 321-326.

Jones, R. (1905). Huntington's chorea and dementia. Lancet, 2, 1831-1832.

Kalkhof, J. and Ranke, O. (1913). Eine neue Chorea HuntingtonFamilie. Zeitschrift für die gesamte Neurologie und Psychiatrie, 17, 256-302.

King, C. (1889). A third case of hereditary chorea. Medical News, $55,39-41$.

Klippel, M., Weil, M. P., and Jacquelin, C. H. (1920). Un cas de chorée chronique héréditaire. Revue Neurologique, 36, 355-358.

Korniloff, A. A. (1889). Chorea chronica hereditaria. Vestnik Klinicheskoi $i$ Sudebnoi Psikhiatrii i Nevropatologii, 6, 38-56.

Kronthal, P. and Kalischer, S. (1895). Weiterer Beitrag zur Lehre von der pathologisch-anatomischen Grundlage der chronischen progressiven Chorea (hereditaria). Virchows Archiv für pathologische Anatomie und Physiologie und für klinische Medizin, 139, 303-318.

Lannois, M. (1888). Chorée héréditaire. Revue de Médecine 8, 645-681.

Lannois, M. and Paviot, J. (1898). Deux cas de chorée héréditaire, avec autopsies. Revue de Médecine, 18, 207-224.

Leese, S. M., Pond, D. A., Shields, J., and Race, R. R. (1952). A pedigree of Huntington's chorea. Annals of Eugenics, 17, 92-112.

Lehmann, W. (1966). Chorea Huntington im Kindesalter. Psychiatrie, Neurologie und Medizinische Psychologie, 18, 210-212.

Lesse, S. M. (1946). Huntington's chorea. Report of a case. fournal of Nervous and Mental Diseases, 104, 84-87.

Lund, J. C. (1860). Chorea Sti Viti i Saetersdalen. In Beretning om Sundhedstilstanden og Medicinalforholdene (Oslo), pp. 137-138.

Lyon, R. L. (1962). Huntington's chorea in the Moray Firth area. British Medical fournal, 1, 1301-1306.

Mackay, M. (1904). Hereditary chorea in eighteen members of a family, with a report of three cases. Medical News (New York) 85, 496-499.

Margulis, M. S. (1913/1914). Beiträge zur Lehre von der Chorea chronica progressiva. Deutsche Zeitschrift für Nervenheilkunde, 50, 470-502.

Markham, C. H. and Knox, J. W. (1965). Observations on Huntington's chorea in childhood. Fournal of Pediatrics, 67, 46-57.

McLearn, J. C. (1885). A case of chorea of fifteen year's standing in a man aged fifty-six. Lancet, 1, 337-338.

Meggendorfer, F. (1923). Die psychischen Störungen bei der Huntingtonschen Chorea, klinische und genealogische Untersuchungen. (Zugleich Mitteilung 11 neuer Huntingtonfamilien). Zeitschrift für die gesamte Neurologie und Psychiatrie, 87, 1-49.

Meggendorfer, F. (1925). Eine interessante Huntingtonfamilie. Zeitschrift für die gesamte Neurologie und Psychiatrie, 92, 655-660.

Menzies, W. F. (1892). Cases of hereditary chorea (Huntington's disease). Fournal of Mental Science, 38, 560-568.

Menzies, W. F. (1893). Cases of hereditary chorea (Huntington's disease). fournal of Mental Science, 39, 50-62.

Michel, D., Boucher, M., Dechaume, J. P., and Moreau, P. (1967). Chorée de Huntington juvénile à debut akinétique. Fournal de Médecine de Lyon, 48, 1371-1373.

Mill, G. S. (1906). Huntington's chorea and heredity. British Medical fournal, 2, 1215. 
Minski, L. and Guttmann, E. (1938). Huntington's chorea : a study of thirty-four families. Fournal of Mental Science, 84, 21-96.

Muncey, E. B. (1964). Huntington's chorea. (Mimeographed edition of original field notes. A copy was kindly supplied by $\mathrm{Dr}$ Sheldon C. Reed, Dight Institute of Human Genetics, University of Michigan.)

Musgrave, R. V. (1942). Considerations of Huntington's chorea in Delaware. Delaware State Medical fournal, 14, 88-96.

Myrianthopoulos, N. C. and Rowley, P. T. (1960). Monozygotic twins concordant for Huntington's chorea. Neurology (Minneapolis), 10, 506-511.

Neumayer, E. and Rett, A. (1966). Ein Choreasippe mit rigider Form. Wiener Zeitschrift für Nervenheilkunde und deren Grenzgebiete, 23, 74-83.

Notkin, J. (1931). Convulsive manifestations in Huntington's chorea. Fournal of Nervous and Mental Diseases, 74, 149-160.

Oliver, J. E. (1970). Huntington's chorea in Northamptonshire. British fournal of Psychiatry, 116, 241-253.

Oliver, J. and Dewhurst, K. (1969). Childhood and adolescent forms of Huntington's disease. Fournal of Neurology, Neurosurgery and Psychiatry, 32, 455-459.

Oppenheim, H. and Hoppe, H. H. (1893). Zur pathologischen Anatomie der Chorea chronica progressiva hereditaria. Archiv für Psychiatrie und Nervenkrankheiten, 25, 617-636.

Orbeck, A. L. and Quelprud, T. (1954). Setesdalsrykka (Chorea Progressiva Hereditaria). Dybwad, Oslo.

Osler, W. (1893). Remarks on the varieties of chronic chorea, and a report upon two families of the hereditary form, with one autopsy. fournal of Nervous and Mental Diseases, 18, 97-111.

Osler, W. (1894). Case of hereditary chorea. fohns Hopkins Hospital Bulletin, 5, 119-120.

Owensby, N. M. (1925). Huntington's chorea in a twin child. fournal of Nervous and Mental Diseases, 61, 466-470.

Pache, H. D. (1953). Sitzungen der Müncher Gesellschaft für Kinderheilkunde. Monatsschrift für Kinderheilkunde, 101, 504

Panse, F. (1942). Der Erbchorea: eine Klinisch-genetische Studie. In Sammlung Psychiatrischer und Neurologischer Einzeldarstellung, Vol. 18. Thieme, Berlin.

Parker, N. (1958). Observations on Huntington's chorea based on a Queensland survey. Medical fournal of Australia, 1, 351-359.

Peachell, G. E. (1905). A case of dementia due to Huntington's chorea. Lancet, 2, 1252-1253.

Peretti, J. (1885). Ueber hereditäre choreatische Bewegungsstörungen. Berliner klinische Wochenschrift, 22, 824-827.

Petit, H. (1969). La maladie de Huntington. In Rapports $67 e$ Session, Congrès de Psychiatrie et de Neurologie de Langue Française, Brussels. Masson, Paris.

Pleydell, M. J. (1954). Huntington's chorea in Northamptonshire. British Medical fournal, 2, 1121-1128.

Pleydell, M. J. (1955). Huntington's chorea in Northamptonshire. British Medical fournal, 2, 889.

Popenoe, P. and Brousseau, K. (1930). Huntington's chorea. Journal of Heredity, 21, 113-118.

Prosenz, P. (1966). Diskussion zum Vortrag Neumayer und Rett. Wiener Zeitschrift für Nervenheilkunde und deren Grenzgebiete, 23, 83-84

Quilichini, R. (1965). Contribition à l'Étude des Formes juveniles de la Chorée de Huntington. Thesis, Marseilles.

Recktenwald (1912). Lundborg-Univerrichtsche familiäre Myoklonie bei drei Geschwistern. Zeitschrift für die gesamte Neurologie und Psychiatrie, 8, 500-513.

Reid, J. J. A. (1960). Huntington's chorea in Northamptonshire. British Medical fournal, 2, 650.

Reisch, O. (1929). Studien an einer Huntington-Sippe. Ein Beitrag zur Symptomatologie verschiedener Stadien der Chorea Huntington. Archiv für Psychiatrie und Nervenkrankheiten, 86, 327-359.

Reisman, L. E. and Matheny, A. P. (1969). Genetics and Counselling in Medical Practice, p. 54. C. V. Mosby, St Louis.

Riggenbach, $M$. and Werthemann, A. (1933). Untersuchungen bei einer Sippe von Huntington'scher Chorea. Schweizer Archiv für Neurologie und Psychiatrie, 31, 306-332.

Riggs, C. E. (1901). Three cases of hereditary chorea. fournal of Nervous and Mental Diseases, 28, 519-521.

Rosanoff, A. J. and Handy, L. M. (1935). Huntington's chorea in twins. Archives of Neurology and Psychiatry, 33, 839-841.

Rosenthal, C. (1927). Zur Symptomatologie und Frühdiagnostik der Huntington'schen Krankheit, zugleich ein Beitrag zur klinischen Erbforschung (Degenerationserscheinungen und Konstitu- tionsanomalien in einem Huntingtonstamm). Zeitschrift für die $\Omega$ gesamte Neurologie und Psychiatrie, 111, 254-269.

Russell, J. W. (1894). Two cases of hereditary chorea occurring in twins. Birmingham Medical Review, 35, 31-33.

Saginario, M., Corrente, V., Passeri, S., and Bagnasco, V (1967) La variante rigida della corea di Huntington nell'eta' infantogiovenile. Sistema Nervoso, 5, 288-298.

Samuel, V. N. (1966). Rigid and akinetic form of Huntington's chorea. Fournal of the Indian Medical Association, 47, 336-338.

Schiottz-Christensen, E. (1969). Chorea Huntington and epilepsy in monozygotic twins. European Neurology, 2, 250-255.

Schlesinger, H. (1892). Ueber einige seltenere Formen der Chorea I. Chorea chronica hereditaria. II. Chorea chronica congenita. Zeitschrift für Klinische Medizin, 20, 127-136.

Schob, F. (1927). Über atypische Krankheitsbilder in einer Huntingtonfamilie. Monatsschrift für Psychiatrie und Neurologie, 65, 286-297.

Schönfelder, T. (1966). Kindliche Chorea Huntington, Zeitschrift für Kinderheilkunde, 95, 131-142.

Schultze, F. (1898). Ueber Poly-Para-und Monoclonien und ihre Beziehungen zur Chorea. Deutsche Zeitschrift für Nervenheilkunde, 13, 409-421.

Singer, K. (1962). Huntington's chorea in the Chinese. British Medical fournal, 1, 1311-1312.

Sinkler, W. (1889). Two additional cases of hereditary chorea. fournal of Nervous and Mental Diseases, 15, 69-91.

Sinkler, W. (1892). On hereditary chorea with a report of three additional cases, and details of an autopsy. Medical Record, 41, 281-285.

Sjögren, T. (1935). Vererbungsmedizinische Untersuchungen über Huntingtons Chorea in einer schwedischen Bauernpopulation. Zeitschrift für menschliche Vererbungs- und Konstitutionslehre, 19, 131-165.

Smith, H. (1898). History of a case of Huntington's chorea. Medical Record, 54, 422-423.

Spillane, J. and Phillips, R. (1937). Huntington's chorea in South Wales. Quarterly fournal of Medicine, 6, 403-423.

Stevens, D. and Parsonage, M. (1969). Mutation in Huntington's chorea. Fournal of Neurology, Neurosurgery and Psychiatry, 32, 140-143.

Stone, S. (1932). Chronic progressive chorea (Huntington's disease). New England fournal of Medicine, 207, 974-983.

Stone, T. T. and Falstein, E. I. (1939). Genealogical studies in Huntington's chorea. Fournal of Nervous and Mental Diseases, 89, 795-809.

Suckling, F. (1889). Hereditary Chorea. British Medical fournal, 2,1039 .

Sumner, D. (1962). Amyotrophy in a family with Huntington's chorea. World Neurology, 3, 769-777.

Tay, C. H. (1970). Huntington's chorea: report of a Chinese family in Singapore. Fournal of Medical Genetics, 7, 41-43.

Tibor, A. (1918). Chorea hereditaria progressiva (Huntington). Wiener Medizinische Wochenschrift, 68, 1099.

Tridon, P., Laxenaire, M., Weber, M., and Labourgade, F. (1964). Forme infantile de chorée de Huntington. Revue Neurologique, 110, 531-535.

Tsuang, M.-T. (1969). Huntington's chorea in a Chinese family. Journal of Medical Genetics, 6, 354-356.

Tyszkiewicz, M. (1960). Szereg przypadkow plasawicy Huntingtona, schizofrenii przewleklej $i$ innych schorzen psychicznych, wystepujacych $\mathrm{w}$ obrebie jednej rodziny. Neurologia, Neuro chirurgia i Psychiatria Polska, 10, 121-124.

Wechsler, I. S. (1920). Chronic non-degenerative hereditary chorea. Fournal of Nervous and Mental Diseases, 51, 348-349.

Werner, A. and Folk, J. J. (1968). Manifestations of neurotic conflict in Huntington's chorea. A case history. Fournal of Nervous and Mental Diseases, 147, 141-147.

West, J. G. U. (1884). Chorea in adult males. British Medical fournal, 1,14

Weyrauch, W. (1905). Ueber Chorea chronica progressiva (Huntington'sche Chorea). Münchener medizinische Wochenschrift, 52, 259-261.

Worster-Drought, C. and Allen, I. M. (1929). Huntington's chorea. British Medical fournal, 2, 1149-1152.

Zacher, O. (1888). Ueber einen Fall von hereditärer Chorea der Erwachsenen. Neurologisches Zentralblatt, 7, 34-37.

Zolliker, A. (1949). Die Chorea Huntington in der Schweiz. Schweizer Archiv für Neurologie und Psychiatrie, 64, 448-457.

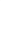

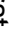

